\title{
PEMBELAJARAN MATEMATIKA DENGAN MODEL SAVI BERORIENTASI PAKEM
}

\author{
Christina Khaidir \\ Program Studi Tadris Matematika, Jurusan Tarbiyah STAIN Batusangkar \\ Korespondensi: Jln. Sudirman No. 137 Kuburajo Lima Kaum, Batusangkar, Sumatera Barat \\ e-mail: christinakhaidir@yahoo.co.id
}

\begin{abstract}
Several international surveys and national examinations show that learning Mathematics in Indonesia have not expected optimum result. This is not only indicated by students' low test score only but also by their low interest and negative image on the subject. In response to the above phenomena, paradigm in education, especially in learning Mathematics begins to shift from learning that places students as passive knowledge receivers into facilitating them to construct active knowledge. This article discusses learning model of SAVI (Somatic, Auditory, Visual and Intellectual) that promotes students' active and independent learning based on PAKEM (active, creative, effective and fun learning). It is, therefore, expected that the offered model improve students' interest and their image upon Mathematics subject as well.
\end{abstract}

Kata kunci: pembelajaran matematika, model pembelajaran SAVI, pembelajaran berorientasi PAKEM.

\section{PENDAHULUAN}

$\mathrm{P}$ ada umumnya hasil pembelajaran matematika di Indonesia di SMA masih jauh dari memuaskan, bahkan kadang-kadang boleh dikatakan masih mengecewakan. Hal ini dapat dilihat dari hasil Nilai Ujian Nasional (UN) dari tahun ke tahun, untuk matematika termasuk dalam kategori "rendah". Meskipun sudah banyak dilakukan penataran-penataran guru dalam rangka inservice training untuk meningkatkan mutu pembelajaran matematika di SMA yang pada gilirannya diharapkan akan dapat meningkatkan prestasi siswa dalam matematika, pada kenyataannya belum menunjukkan kemajuan yang berarti. Sehingga harus diterima sebagai kenyataan bahwa pengelolaan pembelajaran di lapangan masih banyak dijumpai berbagai kesulitan dan kendala, baik dari segi pengelolaan pembelajaran dari guru maupun dari sisi pemahaman siswa.

Paradigma baru pendidikan, menurut Zamroni (dalam Sutarto Hadi, 2000), seharusnya memiliki ciri-ciri sebagai berikut:

1. Pendidikan lebih menekankan pada proses pembelajaran (learning) dari pada pengajaran (teaching)

2. Pendidikan diorganisir dalam suatu struktur yang fleksibel.

3. Pendidikan memperlakukan peserta didik sebagai individu yang memiliki karakteristik khusus dan mandiri, dan

4. Pendidikan merupakan proses yang berkesinambungan dan senan-tiasa berinteraksi dengan lingkungan.

Mengacu pada rambu-rambu Pelaksanaan Kurikulum Tingkat Satuan Pendidikan (KTSP), beberapa hal yang 
perlu diperhatikan dalam pelaksanaan kegiatan pembelajaran di antaranya adalah:

1. Mengkondisikan siswa untuk menemukan kembali rumus, konsep, atau prinsip dalam matematika melalui bimbingan guru, agar siswa terbiasa melakukan penyelidikan dan menemukan sesuatu.

2. Pemecahan masalah merupakan fokus dalam pembelajaran matematika.

3. Dalam setiap kesempatan, pembelajaran matematika hendaknya memulai pengenalan masalah yang sesuai dengan situasi (contextual problem). Dengan mengajukan masalah-masalah kontekstual secara bertahap siswa dibimbing untuk menguasai konsep-konsep matematika.

Di samping itu sampai saat ini anggapan di lapangan mata pelajaran matematika masih merupakan mata pelajaran yang cenderung kurang menarik dan sukar bagi siswa. Demikian juga melihat hasil UN dari matematika secara umum belum menunjukkan hasil yang menggembirakan, jadi efektifitas pembelajaran belum menunjukkan memperoleh taraf yang tinggi. Dengan demikian belum ada indikasi bahwa pembelajaran matematika merupakan mata pelajaran yang menarik dan menyenangkan bagi siswa. Untuk menjawab tantangan ini dan mencermati perkembangan pembelajaran matematika di dunia dewasa ini, maka dikembangkanlah strategi pembelajaran matematika menggunakan model SAVI yang mengacu kepada pembelajaran yang Aktif, Kreatif, Efektif dan Menyenangkan (PAKEM).

\section{MODEL MATEMATIKA BER- ORINTASI PAKEM}

Pembelajaran matematika yang aktif, kreatif, efektif dan menyenangkan
(PAKEM) pada hakikatnya adalah suatu strategi pembelajaran terpadu, yang menggunakan strategi, metoda, pendekatan dan teknik pengajaran terpadu sedemikian rupa baik prosedur maupun tujuan pembelajarannya dapat terlaksana dan tercapai dengan baik. Menyimak pemaparan Fajar Shadiq (2001), masalah trend dan berbagai issue tentang pembelajaran matematika dewasa ini, dapat dikatakan bahwa pembelajaran PAKEM dikembangkan, atas dasar tuntutan karena perubahan paradigma pembelajaran matematika. Berikut ini diutarakan secara sekilas strategi PAKEM yang dikembangkan untuk mencapai tujuan pembelajaran matematika:

\section{Pembelajaran Aktif dalam Mate- matika}

Menurut Taslimutoharom (2006) proses belajar dapat dikatakan active learning apabila mengandung:

a. Komitmen (Keterlekatan pada tugas),

berarti, materi, metode dan strategi pembelajaran bermanfaat untuk siswa (meaningful), sesuai dengan kebutuhan siswa (relevant) dan bersifat pribadi (personal).

b. Tanggung jawab (Responsibility), Merupakan suatu proses belajar yang memberi wewenang pada siswa untuk krtitis, guru lebih banyak mendengar daripada bicara, menghormat ide-ide siswa, memberi pilihan dan memberi kesempatan pada siswa untuk memutuskan sendiri.

c. Motivasi,

Motivasi intrinsik dan motivasi ekstrinsik, dengan lebih mengembangkan motivasi intrinsik siswa agar proses belajar yang ditekuninya muncul berdasarkan, minat dan inisiatif sendiri, bukan karena dorongan lingkungan atau orang lain. 
Proses belajar active learning ini dapat dikembangkan dalam pembelajaran matematika, misalnya pada pembahasan materi trigonometri. Siswa dimotivasi untuk mau mempelajari materi ini dengan mengemukakan manfaatnya. Salah satunya dengan mempelajari materi ini siswa dapat memprediksi ketinggian sebuah gedung dengan memanfaatkan sudut elevasi pada trigonometri. Motivasi intrinsik dan ekstrinsik dapat lahir dalam diri setiap siswa karena siswa merasakan manfaat langsung sehingga dalam pembelajaran akan tumbuh rasa tanggung jawab pada diri siswa tersebut.

\section{Pembelajaran Matematika yang Kreatif}

Apabila pembelajaran aktif penekanannya adalah bagaimana siswa secara aktif mengkonstruksi pemahamannya tentang sesuatu yang dipelajarinya, maka pembelajaran kreatif penekanannya bagaimana guru sebagai fasilitator dalam pembelajaran matematika ini mampu memfasilitasi proses belajar mengajar sehingga memberi suasana yang kondusif untuk siswa belajar. Dengan bermodal pada pengalaman dan pengetahuannya serta mau terus belajar dan mengamati dan berkreasi dengan memanfaatkan lingkungan sekitar, sehingga tercapailah tujuan pembelajaran dengan baik. James E. Stice seorang profesor dari North Carolina University mengajukan saran bagaimana seorang guru kreatif menciptakan suasana belajar agar efektif. Berikut saran-sarannya:

a. Fahamilah apa yang sedang anda bicarakan!

Untuk ini guru tidak boleh lagi berfalsafah boleh "menang semalam" dari muridnya, berbagai survey yang masih diikuti survey berikutnya, akhirnya sampai pada suatu kesimpulan dari hasil penilaian siswa kepada gurunya (sebagai umpan balik), menunjuk- kan bahwa siswa tidak dengan mudah menerima materi pengajaran yang tidak disiapkan oleh gurunya sendiri. Hal ini menuntut guru secara kreatif mempersiapkan materi pembelajaran, tidak sekedar mencomot dari sana sini dan belum dikemas dan dimodifikasikan sesuai dengan kondisi lapangan. Sebagai contoh meskipun di pasaran banyak terjual berbagai buku-buku teks pembelajaran matematika yang berdasar promosinya membantu guru tinggal dilaksanakan di kelas begitu saja, namun jika tidak dilakukan modifikasi oleh guru yang bersangkutan hasilnya tidak optimal.

b. Ajarilah dan kedepankan dengan contoh!

Guru harus menunjukkan bahwa keberhasilan seseorang menjadi mantap secara intelektual, menjadi lebih profesional adalah karena pengetahuan dari hasil belajarnya. Dapat dicontohkan di sini bahwa orang-orang yang berhasil baik dalam bidang ekonomi dan industri maupun dalam dunia politik adalah karena hasil belajar mereka, mereka selalu belajar dan belajar untuk lebih baik lagi.

c. Hargailah siswa anda!

Salah satu bagian dari menghargai siswa adalah membuatnya berani mengajukan suatu pertanyaan dan berani mengetengahkan pendapatnya. Bahwa salah satu keberhasilan guru matematika dalam mengembangkan pembelajarannya adalah menjadikan siswa berani mengajukan pertanyaan dan berani menyatakan pendapatnya.

d. Berilah selalu motivasi siswa anda! Belajar akan menjadi lebih efektif apabila sipebelajar dimotivasi dan disemangati untuk ambil bagian dalam menyelesaikan tugas dalam belajarnya. Pertahankanlah keter- 
tarikan siswa menggunakan materi pelajaran dengan berbagai contoh dan variasinya. Dengan demikian guru dituntut secara kreatif untuk selalu memberi motivasi sepanjang jalannya pembelajaran dan terus mengupayakan ketertarikan siswa tersebut. Sebagai contoh dalam memberi motivasi yang nampaknya sepele tetapi berdasar pengalaman berdampak cukup baik adalah pemberian penghargaan bagai siswa yang telah selesai lebih dulu dengan benar tugas yang diberikan kepadanya setidak-tidaknya pemberian pujian.

e. Konstruksikan selalu tujuan pembelajaran yang akan anda laksanakan!

Dengan telah dikonstruksikan tujuan pembelajaran, maka anda dapat memilih kegiatan-kegiatan kelas, memilih bacaan, dan penetapan tugas rumah yang lebih fokus untuk membantu siswa meningkatkan kemampuannya. Dari sini guru dituntut secara kreatif mengembangkan silabus sehingga mampu diselenggarakannya suatu proses pembelajaran sehingga diwujudkannya kompetensi dasar yang telah ditetapkannya.

f. Ajarilah siswa problem solving skill!

Siswa-siswa mengerti banyak, tetapi tidak banyak dari mereka yang mengerti bagaimana menerapkan pengetahuannya untuk menyelesaikan problem yang belum pernah ia pelajari sebelumnya. Di sini kreatifitas guru dituntut meningkatkan kemampuan problem solving siswa.

g. Katakanlah dan Perlihatkan!

Kebanyakan yang kita ajarkan adalah abstrak. Kita seringkali menerapkan kecanggihan matematika untuk menurunkan suatu relasi, membangun suatu konsep, dan memaksakan dengan itu semua untuk memecahkan masalah. Sehingga sering dijumpai siswa melewati itu semua tanpa memahami secara realitas fenomena pokok yang sedang didiskusikan. Jawablah tantangan itu secara kreatif dengan memvariasikan metodametoda yang dapat membuatnya lebih konkret, atau yang dikenal dengan pembelajaran kontekstual. Dengan merelasikan konsepkonsep dengan situasi dunia real, memberanikan kelompok kerja menggunakan cara apapun untuk dapat mengetuk pintu pengetahuan siswa.

h. Baca dan baca terus model-model pembelajaran!

Terdapat banyak model-model pembelajaran-pemahaman berikut dasar-dasar psikologinya. Belajar tentang berbagai jalan yang dilalui oleh orang yang belajar, adalah langkah pertama untuk mengeliminasi tidak sesuainya (mismatch) antara gaya belajar siswa dengan gaya mengajar anda.

i. Ajarkan siswa anda tentang belajar!

Seseorang dapat anda jadikan figure idola dalam belajarnya dengan style yang berbeda-beda. Secara kreatif anda dapat menceritakan gaya belajar репетu atau gaya belajar Kolb. Demikian juga Dunn dan Dunn (dalam Kemp, 1985), merancang sebuah "catatan gaya belajar" bagi kelompok pelajar usia sekolah dan sebuah instrumen kedua untuk pelajar dewasa, sehingga siswa dapat memilih gaya belajar yang paling mereka sukai. Yang intinya adalah mencari (1) lingkungan jasmani langsung, (2) keadaan perasaan seseorang, (3) kebutuhan seseorang untuk bermasyarakat, (4) kebutuhan jasmani seseorang. 
Dengan memahami gaya-gaya belajar yang dia senangi, siswa dapat menentukan cara belajar yang efektif untuk diri mereka.

j. Konstrusikan test yang valid! Buatlah test yang benar-benar sahih dan reliabel, mengacu kompetensi dasar yang ingin dicapai, dan pengembangan silabus yang telah dirumuskanya. Untuk tingkat sederhana tes yang anda buat dimintakan pertimbangan guru yang lain. (Setiawan; 2010)

\section{Pembelajaran Matematika yang Efektif}

Kanold (dalam Suryanto, 1999) mengemukakan resep pembelajaran efektif, yang meliputi perencanaan, penyajian, dan penutupan sebagai berikut:

\section{a. Perencanaan}

Membuat rencana (di rumah, sebelum mengajar) sehingga dapat:

1) Memulai pertemuan dengan tinjauan singkat atau dengan maslah pembuka selera;

2) Memulai pelajaran dengan pemberitahuan tujuan dan alasan, secara singkat;

3) Menyajikan bahan pelajaran baru sedikit demi sedikit, dan di antara bagian-bagian penyajian yang sedikit itu memberikan kesempatan kepada siswa untuk memahami, mencobakan, bertanya, dan sebaganya;

4) Memberikan petunjuk yang rinci untuk setiap tugas bagi siswa;

5) Memeriksa pemahaman siswa dengan jalan mengajukan banyak pertanyaan dan memberikan latihan yang cukup banyak;

6) Membolehkan siswa bekerjasama sampai pada tingkat siswa dapat mengerjakan tugas secara mandiri.

\section{b. Penyajian}

Mengimplementasikan rencana yang telah dibuat dengan:
1) Pemeriksaan pemahaman oleh siswa dilakukan dengan pemberian tugas kepada siswa. Guru memberikan penjelasan pembuka jalan, kemudian siswa menyelesaikan tugas itu, lalu guru berkeliling memeriksa hasil pembelajaran, memberi bantuan, siswa membuat ringkasan proses langkah-langkah penyelesaian tugas tersebut.

2) Pertanyaan diajukan kepada seluruh siswa; siswa diberi waktu cukup untuk menemukan jawaban; baru kemudian salah seorang siswa ditunjuk secara acak untuk menjawab pertanyaan tadi; akhirnya jawaban ditawarkan kepada siswa lain untuk menilai kebenaran atau ketepatannya.

3) Pada pembelajaran tentang konsep atau prosedur, siswa mengerjakan latihan terbimbing. Guru membimbing dengan menugasi siswa bekerja berkelompok kecil atau berpasangan untuk "merumuskan jawaban atas latihan itu", "menyelidiki pola yang mungkin ada", "menyusun strategi yang diperlukan dalam mengerjakan latihan itu", dan sebagainya.

\section{c. Penutup pertemuan}

1) Jika sisa waktu tinggal sedikit, digunakan untuk membuat ringkasan dari pelajaran yang baru saja selesai.

2) Jika sisa waktu agak banyak, digunakan untuk membicarakan langkah awal dari penyelesaian tugas yang harus dikerjakan di rumah.

Misalnya di dalam taksonomi belajar menurut Gagne, sudut adalah suatu konsep dasar, maka dari beberapa cara untuk mendefinisikan pengertian sudut dapat melalui salah satu pendekatan melalui rotasi garis sebagai berikut:

A

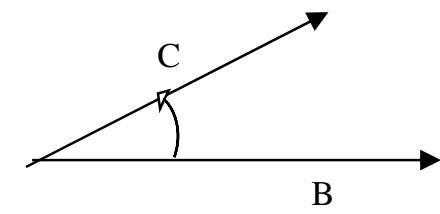


Siswa diminta melukis sinar garis (misal sinar garis $\overrightarrow{A B}$ ) kemudian putar sinar garis $\mathrm{AB}$ tersebut dengan pusat $\mathrm{A}$ sampai terjadi sinar garis AC, sehingga terbentuk sudut BAC (biasanya ditulis dengan $\angle A B C$ ) atau sudut $\alpha$ sebagaimana gambar di atas. Berangkat dari perputaran garis tersebut siswa diajak diskusi, agar masing-masing mengkontruksi konsep sudut pada diri siswa masing-masing. Konsep tentang sudut secara umum didasarkan atas gerak rotasi suatu sinar garis pada titik pangkalnya, dari posisi awal ke posisi akhir. Jadi gambaran sudut BAC di atas sebagai hasil perputaran sinar garis pada titik pangkal A, dimulai dari posisi awal $\overrightarrow{A B}$ dan berakhir pada posisi $\overrightarrow{A C}$. Untuk memberi notasi sudut di atas, dinamai dengan $\angle \mathrm{BAC}$ atau $\angle \mathrm{A}$ atau dengan huruf latin $\alpha$.

\section{Pembelajaran Matematika yang Menyenangkan.}

Motivasi yang merupakan syarat utama agar pembelajaran matematika itu menyenangkan merupakan kunci dari pembelajaran yang efektif. Gagne (dalam Bigge, 1982) menyatakan bahwa motivasi untuk pembelajaran adalah dorongan utama yang mengakibatkan seseorang dengan senang hati, terdorong untuk meraih suatu tujuan. Salah satu hambatan dalam pembelajaran matematika adalah bahwa banyak siswa yang tidak tertarik pada matematika itu sendiri, bahkan beberapa topik di dalamnya sangat tidak disenangi seperti trigonometri.

Dengan adanya motivasi yang baik, siswa akan lebih mudah dan senang belajar matematika. Motivasi dalam pembelajaran matematika adalah usahausaha untuk menyediakan kondisikondisi sehingga seseorang terdorong untuk belajar lebih baik, dan mempengaruhi siswa sehingga pada diri siswa timbul dorongan untuk belajar, sehingga diperoleh pengertian, pengetahuan, sikap dan penguasaan kecakapan, agar lebih dapat mengatasi kesulitan-kesulitan. Tim Instruktur Pemantapan Kerja Guru (PKG) Sekolah Menengah (1994), menyimpulkan sejumlah motivasi yang dapat dikembangkan di sekolah, yang dapat dimanfaatkan untuk menjadikannya siswa menyenangi dan termotivasi untuk belajar matematika SMA, di antaranya:

a. Pemberian nilai

b. Persaingan, di sekolah persaingan sering mempertinggi hasil belajar, baik persaingan individual maupun persaingan kelompok.

c. Kerja sama, jika siswa diminta melakukan tugas bersama-sama, saling bantu membantu dalam menunaikan tugas akan mempertinggi kegiatan pembelajaran dan dapat memupuk hubungan sosial yang sehat.

d. Keterlibatan harga diri, bila siswa merasa pentingnya tugas yang harus diembannya maka ia akan menerima sebagai suatu tantangan dengan mempertaruhkan harga dirinya.

e. Tugas atau pertanyaan yang menantang

f. Pujian

g. Penampilan guru, bahwa guru yang menarik perhatian siswa terha-dap pelajaran dapat menimbulkan minat yang lebih mendalam terhadap pelajaran itu

h. Suasana yang menyenangkan

i. Pengertian, ia akan berusaha untuk mencapainya. tujuan yang menarik bagi siswa adalah motivasi yang sangat baik.

j. Variasi kegiatan belajar, dengan digunakannya bermacam-macam alat bantu pembelajaran, menceritakan sejarah yang berhubungan dengan topik, kegiatan laboratorium dan outdoor mathematics membangkitkan minat dalam belajar matematika. 
k. Matematika sebagai rekreasi, bahwa pengajaran yang disisipi tekateki matematika, permainan dan tebakan yang menyangkut sifatsifat matematika dapat memberikan pengalaman yang menyenangkan terhadap matematika.

\section{MODEL PEMBELAJARAN SAVI YANG BEROENTASI PADA PAKEM}

Pembelajaran tidak otomatis meningkat dengan menyuruh anak berdiri dan bergerak. Akan tetapi menggabungkan gerak fisik dengan aktivitas intelektual dan pengunaan semua indra dapat berpengaruh besar terhadap pembelajaran. Pendekatan belajar seperti tersebut dinamakan dengan pendekatan SAVI. SAVI singkatan dari Somatic, Auditori, Visual dan Intektual. Teori yang pendukung pembelajaran SAVI adalah Accelerated Learning, teori otak kanan/kiri; teori otak triune; pilihan modalitas (visual, auditorial dan kinestetik); teori kecerdasan ganda; pendidikan (holistic) menyeluruh; belajar berdasarkan pengelaman; belajar dengan symbol. Pembelajaran SAVI menganut aliran ilmu kognitif modern yang menyatakan belajar yang paling baik adalah melibatkan emosi, seluruh tubuh, semua indera, dan segenap kedalaman serta keluasan pribadi, menghormati gaya belajar individu lain dengan menyadari bahwa orang belajar dengan cara-cara yang berbeda. Mengkaitkan sesuatu dengan hakikat realitas yang nonlinear, nonmekanis, kreatif dan hidup.

Bobbi De Porter, dkk, 2005, dalam bukunya Quantum Learning, mengemukakan tiga modalitas belajar yang dimiliki seseorang. Ketiga modalitas tersebut adalah modalitas visual, modalitas auditoral, dan modalitas kinistetik (somatis). Pelajar visual belajar melalui apa yang mereka lihat, pelajar auditorial melakukan melalui apa yang mereka dengar, dan pelajaran kinestetik belajar lewat gerak dan sentuhan.

Unsur-unsurnya mudah diingat, yaitu:

1. Somatis : Belajar dengan bergerak dan berbuat

2. Auditori : Belajar dengan berbicara dan mendengar

3. Visual : Belajar dengan mengamati dan menggambarkan

4. Intelektual: Belajar dengan memecahkan masalah dan merenung

Sesuai dengan singkatan dari SAVI sendiri yaitu Somatic, Auditori, Visual dan Intektual, maka karakteristiknya ada empat bagian yaitu:

1. Somatic

"Somatic" berasal dari bahasa yunani yaitu tubuh - soma. Jika dikaitkan dengan belajar maka dapat diartikan belajar dengan bergerak dan berbuat. Sehingga pembelajaran somatic adalah pembelajaran yang memanfaatkan dan melibatkan tubuh (indera peraba, kinestetik, melibatkan fisik dan menggerakkan tubuh sewaktu kegiatan pembelajaran berlangsung).

2. Auditori

Belajar dengan berbicara dan mendengar. Pikiran kita lebih kuat daripada uyang kita sadari, telinga kita terus menerus menangkap dan menyimpan informasi bahkan tanpa kita sadari. Ketika kita membuat suara sendiri dengan berbicara beberapa area penting di otak kita menjadi aktif. Hal ini dapat diartikan dalam pembelajaran siswa hendaknya mengajak siswa membicarakan apa yang sedang mereka pelajari, menerjemahkan pengalaman siswa dengan suara. Mengajak mereka berbicara saat memecahkan masalah, membuat model, mengumpulkan informasi, membuat rencana kerja, menguasai keterampilan, membuat tinjauan pengalaman belajar, atau men- 
ciptakan makna-maknan pribadi bagi diri mereka sendiri.

3. Visual

Belajar dengan mengamati dan menggambarkan. Dalam otak kita terdapat lebih banyak perangkat untuk memproses informasi visual daripada semua indera yang lain. Setiap siswa yang menggunakan visualnya lebih mudah belajar jika dapat melihat apa yang sedang dibicarakan seorang penceramah atau sebuah buku atau program computer. Secara khususnya pembelajar visual yang baik jika mereka dapat melihat contoh dari dunia nyata, diagram, peta gagasan, ikon dan sebagainya ketika belajar.

4. Intektual

Belajar dengan memecahkan masalah dan merenung. Tindakan pembelajar yang melakukan sesuatu dengan pikiran mereka secara internal ketika menggunakan kecerdasan untuk merenungkan suatu pengalaman dan menciptakan hubungan, makna, rencana, dan nilai dari pengalaman tersebut. Hal ini diperkuat dengan makna intelektual adalah bagian diri yang merenung, mencipta, dan memecahkan masalah.

Oleh karena pembelajaran SAVI sejalan dengan gerakan Accelerated Learning (AL), maka prinsipnya juga sejalan dengan AL yaitu:

1. pembelajaran melibatkan seluruh pikiran dan tubuh

2. pembelajaran berarti berkreasi bukan mengkonsumsi.

3. kerjasama membantu proses pembelajaran

4. pembelajaran berlangsung pada benyak tingkatan secara simultan

5. belajar berasal dari mengerjakan pekerjaan itu sendiri dengan umpan balik.
6. emosi positif sangat membantu pembelajaran.

7. otak-citra menyerap informasi secara langsung dan otomatis.

Beberapa ciri-ciri yang mencerminkan gaya belajar tersebut adalah:

1. Belajar visual senang menggambar diagram, gambar, dan grafik, serta menonton film. Mereka juga suka membaca kata tertulis, buku, poster berslogan, bahan belajar berupa teks tertulis yang jelas.

2. Pembelajaran auditori dengan mendengar informasi baru melalui penjelasan lisan, komentar dan kaset. Mereka senang membaca teks kunci dan merekamnya di kaset

3. Pembelajaran fisik (somatis) senang pembelajaran praktik supaya bisa langsung mencoba sendiri. Mereka suka berbuat saat belajar, misalnya: menggaris bawahi, mencorat-coret, menggambarkan.

\section{KERANGKA PERENCANAAN PEMBELAJARAN SAVI}

Pembelajaran SAVI dapat direncanakan dan kelompok dalam empat tahap:

1. Tahap persiapan (kegiatan pendahuluan)

Pada tahap ini guru membangkitkan minat siswa, memberikan perasaan positif mengenai pengalaman belajar yang akan datang, dan menempatkan mereka dalam situasi optimal untuk belajar.Secara spesifik meliputi hal:
a. memberikan sugesi positif
b. memberikan pernyataan yang memberi manfaat kepada siswa
c. memberikan tujuan yang jelas dan bermakna
d. membangkitkan rasa ingin tahu 
e. menciptakan lingkungan fisik yang positif.

f. menciptakan lingkungan emosional yang positif

g. menciptakan lingkungan sosial yang positif

h. menenangkan rasa takut

i. menyingkirkan hambatan-hambatan belajar

j. banyak bertanya dan mengemukakan berbagai masalah

k. merangsang rasa ingin tahu siswa

1. mengajak pembelajar terlibat penuh sejak awal.

2. Tahap Penyampaian (kegiatan inti) Pada tahap ini guru hendaknya membantu siswa menemukan materi belajar yang baru dengan cara menari, menyenangkan, relevan, melibatkan pancaindera, dan cocok untuk semua gaya belajar. Hal- hal yang dapat dilakukan guru:

a. uji coba kolaboratif dan berbagi pengetahuan

b. pengamatan fenomena dunia nyata

c. pelibatan seluruh otak, seluruh tubuh

d. presentasi interaktif

e. grafik dan sarana yang presentasi brwarna-warni

f. aneka macam cara untuk disesuaikan dengan seluruh gaya belajar

g. proyek belajar berdasar kemitraan dan berdasar tim

h. latihan menemukan (sendiri, berpasangan, berkelompok)

i. pengalaman belajar di dunia nyata yang kontekstual

j. pelatihan memecahkan masalah
3. Tahap Pelatihan (kegiatan inti)

Pada tahap ini guru hendaknya membantu siswa mengintegrasikan dan menyerap pengetahuan dan keterampilan baru dengan berbagai cara. Secara spesifik, yang dilakukan guru yaitu:

a. aktivitas pemrosesan siswa

b. usaha aktif atau umpan balik atau renungan atau usaha kembali

c. simulasi dunia-nyata

d. permainan dalam belajar

e. pelatihan aksi pembelajaran

f. aktivitas pemecahan masalah

g. refleksi dan artikulasi individu

h. dialog berpasangan atau berkelompok

i. pengajaran dan tinjauan kolaboratif

j. aktivitas praktis membangun keterampilan

k. mengajar balik

4. Tahap penampilan hasil (kegiatan penutup)

Pada tahap ini guru hendaknya membantu siswa menerapkan dan memperluas pengetahuan atau keterampilan baru mereka pada pekerjaan sehingga hasil belajar akan melekat dan penampilan hasil akan terus meningkat. Halhal yang dapat dilakukan adalah:

a. penerapan dunia nyata dalam waktu yang segera

b. penciptaan dan pelaksanaan rencana aksi

c. aktivitas penguatan penerapan

d. materi penguatan prsesi

e. pelatihan terus menerus

f. umpan balik dan evaluasi kinerja

g. aktivitas dukungan kawan

h. perubahan organisasi dan lingkungan yang mendukung. 


\section{DAFTAR RUJUKAN}

Bobbi De Porter, dkk. 2005. Quantum Learning. Jakarta: PT. Mizan Publika

Fajar Shadiq. 2001. Effective Mathematics Teaching Strategies Inspiring

Progressive Students (suatu makalah disajikan pada "Pemaparan Hasil Pelatihan RECSAM 2") tanggal 18 Juni 2001). Yogyakarta: PPPG Matematika

Setiawan. 2010. Bahan Ajar Diklat Pengembangan Matematika SMA Jenjang Dasar. Jakarta: Departemen Pendidikan Nasional Direktorat Peningkatan Mutu Pendidik Dan Tenaga Kependidikan Pusat Pengembangan Dan Pemberdayaan Pendidik Dan Tenaga Kependidikan Matematika

Indeks

belajar. 52, 53, 54, 55, 56, 57, 58, 59, 60 guru ...... 1, 52, 53, 54, 55, 56, 57, 59, 60 konsep $52,54,56$ masalah $52,54,58,59,60$ model $1,52,55$

Suparlan, dkk. 2009. PAKEM (Pembelajaran Aktif, Kreatif, Efektif, dan Menyenangkan. Bandung: PT Genesindo

Suryanto. 1999. Matematika Humanistik sebagai Pembelajaran yang Aktif-Efektif. Yogyakarta: PPPG Matematika

Sutarto Hadi. 2000. Teori Matematika Realistik. Enshede: University of Twente.

Taslimutoharom. 2006. Active Learn-ing. Jakarta: PT. Gramedia

Tim Instruktur PKG Matematika SMU. 1994. Beberapa Metode dan Ketrampilan dalam Pengajaran Matematika. Yogyakarta: Direktorat Pendidikan Menengah Umum, Depdiknas.

pembelajaran ... 1, 52, 53, 54, 55, 56, 57, $58,59,60$

Pendidik 60

prestasi.

siswa1, 52, 53, 54, 55, 56, 57, 58, 59, 60 strategi 52,56 